\title{
Obligations of international assistance and cooperation in the context of investment law
}

\author{
Tara Van $\mathrm{Ho}^{1}$
}

\section{Introduction}

This Chapter considers states' obligations to provide international assistance and cooperation (IAC) for the protection and realisation of human rights in the context of international investment law (IIL). It focuses on the obligations arising from Article 2(1) of the International Covenant on Economic, Social, and Cultural Rights (ICESCR) (1966). This is only one potential avenue for establishing extraterritorial human rights obligations in the context of IIL, but it is one that has not yet been seriously considered. As this Chapter concludes, a more structured and fully developed understanding of what Article 2(1) requires of states has the potential to upend current approaches to the relationship between IIL and international human rights law (IHRL).

IIL provides substantive protections to foreign investors, primarily businesses, when they undertake commercial investments outside their state of nationality (their 'home state') (Yilmaz Vastardis 2018). ${ }^{2}$ There is neither a universal investment treaty nor a coherent body of interpretation and application of IIL. Its protections derive from bilateral and multilateral international investment agreements (IIAs), domestic investment laws, and direct contracts between an investor and a state. Conflicts between IIL and IHRL remain rare (see Coleman, Cordes and Johnson 2020) but, as is explained in Section 3, IIL can effectively constrain states' ability to respect, protect, and fulfil their IHRL obligations. This Chapter considers states' IAC obligations to address IIL impacts. Because this is the first sustained examination of the responsibility of IAC in the context of IIL, it focuses only IIAs as the treaties, unlike a state's contracts or national laws, require and invite the involvement of more than one state.

To date, scholarship has considered how ICESCR's IAC obligations might inform the analysis of particular issues within IIL. As such, scholars have narrowly focused on the obligations of investors' home states when developing and negotiating IIAs (Maastricht Principles 2013; De Schutter 2011; Davitti 2019, pp. 207-216) and when providing financial support to investors operating overseas (Krajewski 2013; Ruggie 2011, Principle 4), or to protect human rights by ensuring accountability for national investors that operate abroad (Sornarajah 2015, p. 320). This Chapter starts from a different position, centring the demands of IAC and asking about their implications for IIL. By looking at what is broadly required of states with regard to IAC (Section 2) before outlining the impact IIL has on IHRL (Section 3), I set a foundation to assess 
the responsibility of negotiating states (Section 4). I am also able to reveal IAC obligations on third-party states in the context of IIL (Section 4). In this, I break novel ground. I conclude (Section 5) that the recognition of third-party obligations for IAC in the context of IIL has the potential to alter the existing relationship between IIL and IHRL, and raises further questions for scholars and practitioners.

\section{Defining international assistance and cooperation obligations}

ICESCR Article 2(1) requires states parties to 'take steps, individually and through international assistance and cooperation, especially economic and technical, to the maximum of [their] available resources' to realise the rights in the Covenant. It is complemented by three other articles in ICESCR. States recognise in Article 15 that international cooperation in the scientific and cultural fields can facilitate realisation of the Covenant and in Article 23 that they must undertake 'international action for the achievement' of the Covenant's obligations, including providing technical assistance and establishing fora for international cooperation. States uniquely agree to provide IAC, including technical assistance around issues of nutrition and agrarian reform, in Article 11. The commitment in Article 2(1), however, clarifies that the obligation to IAC does not operate in isolation but attaches to each right and to conduct that influences realisation of the Covenant as a whole.

Historically, the phrasing of Article 2(1) raised questions as to whether states merely must seek IAC when they need it, or if they are also required to provide IAC as well (Karimova 2014; Skogly 2006; Sepúlveda 2006). As I explain in this section, the UN Committee on Economic, Social, and Cultural Rights (CESCR) has now clarified that states carry obligations to provide IAC when they have the capacity to do so. For the purpose of this Chapter, I accept the jurisprudence of CESCR is, at the least, a highly persuasive interpretation of ICESCR representative of the 'teaching of the most highly qualified publicists of the various nations' (ICJ Statute 1946, art. 38(1)(d)) who have been entrusted by states parties to oversee compliance with the treaty and clarify the content of substantive commitments (Optional Protocol to ICESCR 2009). Their interpretation should be disregarded only with good reason and when displaced by a more persuasive interpretation.

CESCR 'has given little detailed direction as to the content of the obligation' to IAC (Salomon 2013, p. 279), and there remains limited scholarship examining the demands of IAC (cf., Sepúlveda 2006; Karimova 2014; Maastricht Principles 2013). Primarily, as is seen below, the focus thus far has been on framing the responsibility rather than elaborating specific obligations. Pulling together what does exist on IAC, as I do here, provides an important foundation for understanding states' obligations in the context of IIL. I examine how the framing of IAC obligations before identifying specific obligations pertinent to IIL.

\section{Framing the obligations}

CESCR has recognised that all states carry IAC obligations (e.g., CESCR 2000a, paras. 43-45), but, as noted above, the question has long been whether states who can provide IAC must do so (Karimova 2014; Skogly 2006; Sepúlveda 2006). To answer this, CESCR and noted scholars have framed IAC in two significant ways. First, they placed the IAC obligations in the context of the 'respect, protect, and fulfil' framework (CESCR 2017; Eide 1999; Skogly 2006; Sepúlveda 2006; De Schutter 2011; Vandenhole and Benedek 2012; Maastricht Principles 2013). That each human right entails three distinct state obligations - respect, protect, and fulfil - is now widely accepted (e.g., CESCR 2000a, para. 33; Human Rights Committee 2004, paras. 6-7; Mégret 
2017, p. 130). States must respect human rights by refraining from interfering in their realisation, protect by preventing third-party actors from harming rights, and fulfil by adopting legislative, judicial, administrative, and educative measures aimed at ensuring the highest realisation of the right as is possible in light of financial and other practical constraints (Eide 1999, para. 130). Linking IAC to the tripartite obligations provides an interpretation of IAC consistent with other substantive obligations in ICESCR, clarifies when, how, and why responsibilities arise in areas that CESCR has not yet addressed or addressed fully, and allows states to distinguish between obligations of immediate effect-generally obligations of outcome to 'respect' human rights - and obligations of conduct aimed at the progressive realisation of rights in the Covenant, generally to 'protect' and 'fulfil'.

Second, the responsibility to provide IAC has been linked to states' capacity to give it (e.g., CESCR 2020, para. 35). CESCR has indicated 'that it is particularly incumbent on states parties and other actors in a position to assist, to provide' IAC in order to ensure all states parties can meet minimum core obligations (ibid, para. 45). It has repeated its exhortation that those 'in a position to assist' must do so in other General Comments and in state reports (CESCR 2016, para. 66; 2008, paras. 55-56; 2013, para. 32; 2018, paras. 20-21). CESCR's approach is buttressed by the Maastricht Principles on the Extraterritorial Obligations of States in the Area of Economic, Social, and Cultural Rights (2013, Principle 31) — developed by leading experts and relied upon by CESCR (2017, fn 71) and UN special procedure holders (e.g., Dandan 2016, paras. 30-36; Lumina 2014, paras. 37-41) — which indicate that obligations should be 'commensurate with' the state's 'economic, technical and technological capacities, available resources, and influence in decision-making processes'.

The focus on a state's capacity to provide is often presented as imposing obligations on 'developed states' to provide assistance and cooperation to 'developing states', but as Skogly (2006) has pointed out, this is inaccurate. The obligation applies equally to all states and is often an obligation of conduct rather than outcome. Developing states can use leverage, individually or collectively, to influence the international community, even where they lack the power to directly provide IAC (Vandenhole and Benedek 2012, p. 341). And, since 'capacity' includes various types of knowledge and resource, there are times when developing states' capacity and technical knowledge will be greater than developed states or international organisations who have never faced the constraints they do. For example, several developing states with experience in public health crises have thus far weathered the COVID-19 pandemic with less technology but better results than many developed states (e.g., Makoni 2020). Given their experience, the former category can assist other states in planning and assessing COVID-19 responses, and would have a responsibility to do so to the extent they can.

\section{Identifying relevant IAC obligations for IIL}

As noted above, CESCR has not fully addressed states' IAC obligations in the context of IIL. It has, however, identified some relevant obligations. In the context of IAC, the respect obligation requires states to refrain from any direct or indirect action that would interfere with the full realisation of rights in another territory (CESCR 2017, para. 29). When operating abroad, states and their state-owned enterprises should apply their domestic standards when those standards provide greater respect for human rights than the host state's laws and regulations (CESCR 2016, para. 69). States must not impose 'burdensome conditionalities' as part of their official development assistance programmes or adopt 'measures which are not guided by the needs of developing countries' (Sepúlveda 2006, pp. 281-282). Finally, states should be cognisant of how their trade and investment agreements impact human rights extraterritorially and ensure those 
agreements do not negatively impact economic, social, and cultural rights (CESCR 2017, para. 29; 2016, para. 72).

The duty to protect requires, inter alia, responding to the extraterritorial impacts of thirdparty actors (CESCR 2000a, para. 39; 2017, para. 30;2020, para. 84). Primarily, states are to adopt legislation and other measures aimed at 'prevent[ing] and redress[ing] infringements of Covenant rights that occur outside their territory due to the activities of business entities over which they can exercise control' (CESCR 2020, para. 84; 2016, para. 70). Claire Methven O'Brien (2018, pp. 60-61) has argued that this obligation has been prematurely pronounced, a minority position amongst scholars (e.g., McCorquodale and Simons 2007; Seck 2011; De Schutter 2016; Davitti 2016). Methven O'Brien utilises jurisprudence from the European Court of Human Rights, with some insights from the International Court of Justice, to argue businesses' home states do not have jurisdiction over the victims of its business nationals operating abroad. As such, she submits that states do not owe any obligations to those harmed by the overseas operations of their corporate nationals. But, Methven O'Brien's objection is misplaced when considering states' IAC obligations. IAC is not tied to states' jurisdiction but to their capacity to provide assistance (e.g., CESCR 2020, para. 45). As is explained below, IIAs do not affect the relationship between a business and its home state, and as such home states are often in a greater position to regulate a business's extraterritorial impacts than the host state. That capacity is the metric by which to measure the state obligation, and that capacity suggests that in many cases there is an IAC obligation to regulate business nationals' extraterritorial impacts.

Finally, to 'fulfil', states should 'promote an enabling environment' that facilitates the advancement of economic, social, and cultural rights (CESCR 2020, para. 77). This includes ensuring their overseas development assistance takes account of human rights (CESCR 2017, para. 24; Eide 1999, para. 130; Sepúlveda 2006, p. 285) and that the international organisations they are members of respect, protect, and fulfil human rights (CESCR 2001, para. 31). CESCR has repeatedly stressed the importance of States Parties to the International Monetary Fund, the World Bank, and regional development banks monitoring and influencing the organisations' policies for the protection of human rights (e.g. CESCR 2000b, para. 126; 2001, para. 394; 2016, paras. 71-72; Maastricht Principles 2013, p. 10). This is recognised as an obligation of effort relative to the influence of the state (ibid). Less influential states may fulfil their obligations by raising points for debate and forming alliances in order to influence policy and practices (Vandenhole and Benedek 2012, p. 341).

Despite the limited development of IAC to date, as is seen below, what exists provides an important foundation for considering IAC in IIL. It is now necessary to consider how IIL harms, or threatens to harm, human rights so as to identify ways in which states' IAC obligations are triggered.

\section{The impact of IIL on IHRL}

Disputes arising from IIAs are generally decided by ad hoc investor-state dispute settlement ('ISDS') panels appointed by the state and the complaining foreign investor (Yilmaz Vastardis 2020a; Sornarajah 2015, pp. 139-140). The World Bank has been the primary advocate of ISDS, based largely on a theoretical belief in its ability to facilitate foreign direct investment, and 'is the only [international organization] that has ever recommended governments provide access to investor-state arbitration in their domestic investment laws' (Berge and St John 2020, p. 5; see also Sattorova 2018). States sometimes condition the provision of IAC on a recipient state receiving guidance from the World Bank, and the Bank's guidance has encouraged states, particularly developing states, to adopt ISDS (ibid). Yet, ISDS tribunals rarely engage with IHRL 
in any significant manner, providing only '[s] uperficial acknowledgments of human rights law ... unlikely to produce harmonized obligations' (Coleman, Cordes and Johnson 2020, p. 294). Decisions cannot be appealed, can be annulled only in rare circumstances, and are enforceable in the defending state and in up to 185 other states or territories (ICSID Convention 1966; New York Convention 1958). As Yilmaz Vastardis (2018, p. 280; also, 2020) has rightly argued, the current ISDS 'prioritises institutions of justice for foreign investors over the improvement of local institutions that could provide justice for members across society, including', but not limited to, foreign investors (see also Arcuri 2020).

This section cannot exhaustively examine the threats IIL poses to IHRL (see Davitti 2019; Wandahl Mouyal 2018), but highlights three dominant issues that affect states' ability and willingness to protect human rights: (1) the inconsistency of ISDS tribunal decisions; (2) the failure to recognise investors' responsibilities for human rights; and (3) the significant costs of ISDS. Collectively, these facets incentivise states to prioritise IIL at the expense of human rights (Bonnitcha 2011, p. 128; Van Ho 2016).

ISDS panels operate without binding precedent or jurisprudence constante (e.g. Schneiderman 2010). After Argentina placed caps on water and energy tariffs in furtherance of the human rights to water and an adequate standard of living during its 2001 financial crisis, various ISDS panels disagreed on pretty much everything: whether Argentina was in a position to invoke the defence of necessity; when the crisis started and ended; and why the state was or was not justified in its response, including the relevance of its IHRL obligations (e.g. ICSID 2007b; 2007a; 2010; 2008b; 2016; Zarra 2018, pp. 151-154). These are not the only cases with different outcomes arising from the same underlying facts and IIL protections merely because the claimants and tribunals differed (e.g. ICSID 2012;2017). Nor are they alone in creating what might best be called IIL's jurisprudence incohérente, ${ }^{4}$ which makes it difficult for states to know when or how they can protect human rights (e.g. Bonnitcha 2011; Zarra 2018, pp. 140-141). The limited means of challenging ISDS decisions makes the jurisprudence incohérente an embedded and pernicious feature in IIL.

ISDS panels have generally ignored investor responsibilities for human rights, even when human rights are a salient aspect of the business's operations. For example, the tribunal in Biwater Gauff v. Tanzania (2008, para. 149-152) found the investor underestimated the work necessary to operate Dar es Salaam's privatised water services. After the water services declined and the investment was, according to the Tribunal, rendered valueless by the investor's conduct, the state seized the company's assets. Nowhere-other than in a recitation of an amici curiae submission (ibid, paras. 356-391) — did the tribunal consider either the state's IHRL obligations or the investors' human rights responsibilities relevant. Instead, it found the state breached IIL but owed no reparations because of the value of the investment. The tribunal could justify finding the state breached IIL by ignoring the state and investors' human rights responsibilities instead of analysing whether the state owed an IHRL obligation to intervene in the investor's obligation. This approach effectively limits the actions states like Tanzania can take against investors to protect human rights.

This danger was repeated in Urbaser v. Argentina (2016), where the tribunal considered the first state counterclaim to assert that an investor was liable for breaching human rights standards by failing to fulfil promised reforms and investments in a water concession (ibid, para. 1128). But, the tribunal determined that the investor owed no positive IHRL obligations despite the inherent impact of its operations on human rights. Instead, the tribunal found the state should have included specific human rights obligations in its domestic laws or investment contracts (ibid, para. 1206 et seq). The case was heralded for recognising that states could bring human rights counterclaims in theory (Guntrip 2017; Nica 2018; also see Fahner and 
Happold 2019). Yet, in practice, the substantive treatment of IHRL meant that the Argentinian government could not recoup losses caused by the company's conduct. When considering whether the Argentine government owed a responsibility to renegotiate the concession agreement, the company's previous impact on human rights played no part in the tribunal's assessment.

IIL would not be so dangerous if it were not so costly. Regardless of the outcome of the case, between 2011-2016, states paid an average of US $\$ 5.6$ million to defend ISDS claims (Pelc 2017, p. 566). At one point, the claims against Argentina for its handling of the 2001 financial crisis amounted to around US $\$ 80$ billion (Lavopa 2015, p. 2) while financially strapped Venezuela has been ordered to pay US $\$ 8$ billion in a single case (ICSI 2019). Scholars recognise that the cost and jurisprudence incohérente of IIL can render states unwilling or unable to adopt necessary regulation that harms investors' interests (e.g., Sim 2018; Davitti 2019; Van Ho 2016; Wandahl Mouyal 2018; Meshel 2015; Choudhury 2009). Tribunals have never considered how these types of awards impact the state's ability to meet its IHRL obligations, particularly their obligation to use the maximum of their available resources to fulfil economic, social, and cultural rights. Yet, the costs undermine states' ability to realise their IHRL obligations.

Advocates of IIL have claimed that there is no conflict with IHRL because the principle of systemic integration allows for an integration of the two fields (e.g., Balcerzak 2017). Such claims fail to explain why this theoretical commitment rarely translates into practice. Others have argued that judicialising ISDS would alleviate the underlying problems (e.g., Svoboda 2020), but without any evidence that a standing court would adequately address IHRL. Still others have suggested better drafting of IIAs (Muchlinski 2016), even though the jurisprudence incohérente and limited means of challenging problematic decisions mean clauses may be interpreted or applied inconsistently even with better drafting. These proposals, as Ho (2020) has asserted, are often presented by IIL apologists 'with a pragmatic aura' that allows them to 'refus[e] to engage with the critics on the systemic failings of ISDS' while offering 'peripheral modifications'. Radical reform is needed instead (Ho 2020). States, and the field of IHRL, need to consider how this radical reform can be realised, and applying the demands of IAC to IIL can help in this regard.

\section{Identifying obligations in the context of investment law}

Because scholarship to date has focused on addressing specific problems within IIL, rather than considering more fully the demands of IAC in this context, scholars have developed only a few applications of IAC to state conduct in IIL. Literature has focused on the responsibility of the negotiating parties, who would appear to have the greatest capacity to influence the realisation of IHRL. That premise should be questioned by future scholars in light of the role the World Bank has played in promoting ISDS (Berge and St John 2020). In this section, I set aside the direct responsibility of the World Bank (but see, CESCR 1990; van Genugten 2015) to focus, first, on known responsibilities of negotiating states. I then make the novel argument that thirdparty states also have IAC obligations in the context of IIL.

\section{Respect and protect obligations on negotiating parties}

Thus far, two specific IAC obligations have been identified in the context of IIL: (1) their responsibility to undertake human rights impact assessments (HRIAs); and (2) their responsibility in how they negotiate the IIA. This section briefly delineates both expectations. 


\section{Human rights impact assessments}

The adoption of IIAs entails a balancing of priorities as some individuals, businesses, and investors may benefit from increased foreign investment or opportunities to invest abroad while others are harmed by these developments (De Schutter 2011, Principle 6.1). While states must generally determine for themselves the appropriate balance between interests, CESCR has established a clear and general expectation on states to ensure their investment and trade agreements respect and protect human rights (CESCR 2008, para. 57; CESCR 2017, para. 13; Sepúlveda 2006, p. 282; Eide 1999, para. 130). This expectation was echoed in the UN Guiding Principles on Business and Human Rights (Ruggie 2011, Principle 9) and by other experts (e.g., de Zayas 2015, para. 4; Tauli-Corpuz 2016, para. 93(b); Krajewski 2017, p. 6; Kube 2019, pp. 241-287). Both negotiating states are expected to undertake HRIAs, which must account for general impacts but also for how the IIAs will affect conditions and rights in practice (De Schutter 2011, Principles 2.6 and 5-6). Where the HRIA reveals a negative impact, states are to 'take corrective measures' in the development or implementation of the IIA (Eide 1999, para. 130). The jurisprudence, however, has remained vague: states are to ensure IIAs do not harm human rights. How states are to do this has often been left unaddressed.

To assist states in realising their obligations, De Schutter (2011), in his mandate as UN Special Rapporteur on the right to food, promulgated UN Guiding Principles (UNGPs) on how to conduct HRIAs before concluding IIAs. Unfortunately, the guidance remains general and vague. The UNGPs do not mandate a methodology but call for states to explicitly reference the normative content of their human rights obligations, incorporate indicators, and engage in public consultations over the appropriate balance to be struck within the IIA (ibid, Principles 5-6 and 11). States must be cognisant of how these trade-offs will impact various communities, ensuring they 'never result in a deprivation of the ability of people to enjoy the essential content of their human rights', develop solutions so that 'losses and gains are shared across groups, rather than concentrated on one group', and ensure any trade-offs 'comport with the principles of equity and non-discrimination' (ibid, Principles 6 and 11). Finally, the IIA must not lead to retrogressive measures, which would undermine the progressive realisation of rights within ICESCR (ibid, Principle 11).

Despite the support for HRIAs from CESCR and other experts, and De Schutter's work in identifying a process for this, most states have ignored this obligation (see Dommen 2020, p. 307). It appears the EU has taken the most consistent approach to integrating HRIAs into their broader sustainability impacts, alongside labour and environmental concerns (European Commission 2017, p. 4). The EU claims that these impact assessments are 'a key tool for the conduct of sound, evidence-based and transparent trade negotiations' (ibid). Unfortunately, research indicates that even recent sustainability impact assessments by the EU fail the standards in the UNGPs (Lawrence, Van Ho and Yilmaz Vastardis 2020). The obligation to conduct HRIAs is intended to capture the full range of risks that IIAs can pose for IHRL. Yet, with limited guidance and practice, this obligation has, thus far, done little to advance or protect IHRL.

\section{Negotiating IIAs}

While striking the appropriate balance is primarily an obligation of the host state, negotiating partners are expected to respect this process and refrain from coercive measures that might require a different set of priorities (De Schutter 2011; Davitti 2019). Implicit in CESCR's call for states to ensure their IIAs respect human rights is a responsibility to negotiate a treaty that 
protects human rights both at home and in their negotiating partners' territory. De Schutter (2011) and Davitti (2019) make this explicit, asserting that states' IAC obligations should affect their conduct in the negotiation of treaties. De Schutter (2011) takes a minimalist approach, finding that states must refrain from using their 'economic leverage or other means of influence' to insist on clauses that impede compliance with human rights. This means states must forego economic opportunities they would normally have due to their relative power in order to respect human rights on the territory of another state.

Davitti (2019, pp. 207-216) pushes further. As CESCR (2017, para. 27) has, Davitti argues that customary international law in the context of due diligence obliges home states to ensure their territory is not used to harm human rights in another territory. Given the role of IIL in protecting corporations from accountability, Davitti's approach would oblige home states to negotiate IIAs in a way that accounts for and guards against specific human rights risks that arise from their business nationals operating on the territory of (an)other state(s). This requires concretising the risks posed by a state's nationals through an HRIA and negotiating not only for adequate regulatory space for states but also clear duties on investors to respect human rights. In this, Davitti rebukes Methven O'Brien's proposition, discussed in Section 2, above. Davitti's position suggests a responsibility on states to not only balance their own economic and policy interests - as De Schutter did-but to negotiate against their business interests if needed to protect human rights in a negotiating partner's territory. Neither De Schutter nor Davitti elaborate on what their approach would mean in practice, or how responsibility for specific impacts might be attributed between the parties.

Building on Davitti's argument, one might argue that if states must negotiate against their own interests to conclude human rights compliant IIAs, they should not negotiate IIAs at all. A more nuanced approach might be appropriate. There may be legitimate reasons for establishing investment protections, so long as they comply with IHRL. States have begun to develop clauses aimed at doing this, but such efforts remain limited. Several IIAs explicitly protect states' regulatory space, although these clauses are sometimes limited to environmental, public health, or labour issues without explicitly including human rights (e.g., Sri Lanka and China 1986, art. 11; Botswana and Ghana 2003, art. 5(3); Lawrence, Van Ho and Yilmaz Vastardis 2020, pp. 12 and 15-16). States commonly commit to not weakening their labour or environmental protections, but, again, this rarely includes language for human rights more broadly (e.g., United States 2012, art. 12; Japan and Colombia 2011, art. 21). States have also committed to 'encourag[ing] enterprises ... to incorporate internationally recognized standards of corporate social responsibility in their practices and internal policies' (e.g., Canada and Burkina Faso 2015, art. 16), but in almost all cases they stop short of placing direct obligations on investors. In a rare exception, Morocco and Nigeria (2016, art. 18) included an explicit obligation on investors to 'uphold' and not 'circumvent' human rights, and to act in accordance with ILO core labour standards. That treaty has not yet entered into force, and there is an ongoing debate about whether it is desirable to recognise investor obligations within IIAs or if a better path is to develop those obligations in domestic law in a way that would impact the interpretation of rights and obligations in IIL (e.g., Ho 2019; Perrone 2019; Krajewski 2020). The SADC Model Bilateral Investment Treaty Template (2012, arts. 5.2 and 15) and the Draft Pan-African Investment Code (2016, arts. 8, 10(2), and 19-24) also include clauses that could be used to hold businesses accountable, including minimum standards for human rights.

Relying on better drafting may provide limited benefits for IHRL. As noted above, evolutionary and expansive interpretations of treaties by ISDS panels, their jurisprudence incohérente makes this approach inherently fragile. Additional and alternative developments may be needed to protect human rights. 


\section{Obligations on third-party states}

While the negotiating parties may have the most immediate power, third-party states can have significant direct and indirect influence on the drafting of IIAs. If the obligation provides that IAC is tied to a state's capacity, there needs to be greater consideration of what constitutes power and how it should operate so as to protect IHRL in IIL. If Yilmaz Vastardis's position (2018; $2020 \mathrm{a}$ ) is correct and ISDS itself undermines IHRL by privileging foreign investors and depriving developing states of resources needed for the development of local systems of justice, then power and capacity sits with those who protect and promote the ISDS regime. As mentioned above, states sometimes condition IAC on accepting guidance from the World Bank, and the World Bank in turn encourages states to adopt ISDS. The state conditioning its aid exercises significant power, both in relation to the receiving state and in the choice of the World Bank to provide policy advice. The conditioning states may therefore have IAC obligations. Under Yilmaz Vastardis' approach, these states should work to dismantle the ISDS system, develop local systems of justice capable of providing equal access to justice.

Even if one were to shy away from such a radical position, the conditioning states still seem to have an obligation to ensure the World Bank's guidance respects (and perhaps protects and fulfils) human rights within receiving states. This could be done in a few ways. First, they could have an obligation to ensure the receiving state is exposed to alternative, critical guidance on ISDS, giving the state an opportunity to develop their own policy priorities. The conditioning state should monitor and assess the Bank's guidance in light of the concerns set out in Section 3, above. Such oversight aligns well with the existing expectation on states to ensure that international organisations to which they are a party respect human rights. If the World Bank is committed to promoting ISDS regardless of the needs of a developing state, then requiring engagement with the World Bank may constitute a burdensome conditionality in breach of the conditioning state's ICESCR obligation. States with lesser power would also have an IAC obligation to use the leverage they do have, and to work with other states, to ensure IIL better respects human rights both by engaging the World Bank to influence its guidance and raising pertinent issues or advocating for change in other, relevant international fora such as the UN Conference on Trade and Development and the International Centre on the Settlement of Investment Dispute, both of which have a role in assessing or promoting IIL.

Moving beyond the issue of the World Bank's role, one could argue that various third-party states have different types of capacity and can influence the development of IIL. Developing or middle-income states that have suffered from ISDS decisions that restrict their ability to regulate for human rights - like Argentina — have learned valuable lessons about the balance between IIL and IHRL. These states may not be providing IAC in other ways, or they may not be conditioning their official development assistance on World Bank guidance, but they have gained important insights and technical competency that may not be shared by others states or the World Bank. Akin to states with greater success in combatting COVID-19 sharing their expertise and experience, states that have gained competency on the balance between IHRL and IIL have an obligation to provide guidance to others. Such leadership could manifest in the drafting of model treaty clauses that better protect regulatory space or that limit the level of compensation that can be awarded. As is common with the protect and fulfil obligations, the obligations of leadership generally and of drafting clauses specifically would appear to be obligations of conduct rather than outcome. States must exercise good faith in an effort to better protect human rights in light of ongoing developments within IIL. The possibilities for the exercise of these obligations should be examined more fully than what has occurred before, or than what the constraints of this Chapter allows. Recognising this broader leadership role clarifies that IAC 
imposes obligations both within the negotiation of IIAs but throughout the training, conditions, and international leadership surrounding the development of IIL so that IIL learns how to respect, protect, and fulfil IHRL.

It is significant to recognise that non-negotiating states have IAC obligations. This has the potential to transform the scholarship and practice on IHRL and IIL by expanding the range of duty-holders and the understanding of competency to lead in this area. For example, acknowledging that states that have been the subject of ISDS decisions affecting their IHRL obligations have a particular competency moves the conversation from one that centres the financial power and responsibility of developed states to one that centres the technical and experiential knowledge of other states. These states have IAC obligations to pass on their lessons and assume leadership within the IHRL-IIL discussion. It also prioritises state experience over the World Bank's ideological commitment to ISDS. 'Capacity' within the context of IIL has thus far been so narrowly drawn that these obligations and opportunities have been missed.

\section{Conclusion}

This Chapter has focused on the ICESCR obligation to provide IAC in the context of IIL. This area is under-developed, and merely identifying CESCR's relevant jurisprudence and the full remit of obligations on states negotiating IIAs provides a significant contribution to the literature on IHRL and IIL. I do that in this Chapter before going further. By recognising that CESCR identifies IAC obligations on the basis of capacity to influence change, and that some obligations are of conduct rather than outcome, I am able to establish that third-party states also have IAC obligations in the context of IIL. I explore some of the implications of this, recognising first that those states who condition assistance on World Bank guidance owe obligations to ensure that guidance complies with IHRL. Additionally, I note that capacity can exist in other ways, including technical expertise developed by losing past ISDS cases. Such technical expertise creates an obligation on states that may not otherwise be providing IAC in the context of IIL to provide guidance and to assume a leadership position in debates over the construct and operation of IIAs and ISDS. This has the radical potential to reorder whose experiences and knowledge is valued in discussing the intersection of IIL and IHRL.

The recognition that capacity extends beyond the negotiating states is significant. Rather than looking for small inroads into IIL, this Chapter suggests that centring IAC obligations opens up a stream of new questions. Future scholarship should consider how IAC obligations in ICESCR, and other treaties, might add to the analysis provided here. It should also consider how states' leadership in IIL should manifest, such as whether states must include or advocate for specific (types of) clauses, and at what point would states have an IAC obligation to work to dismantle ISDS. One set of questions this Chapter points to but did not examine relate to the obligations on states to accept IAC. If there is an obligation on states in need of IAC to accept it, one could argue that states developing IIAs must accept guidance from those who have learned from past ISDS decisions. This could give states significant influence over another state's policy choices, and scholars should examine how that relates to challenges, or builds upon, the existing obligation to accept help from states that condition assistance on World Bank guidance. If one accepts that such an obligation exists, are there any corresponding obligation on those states that currently condition assistance on World Bank guidance? This Chapter could not answer these questions, but it provides the foundation for analysing them in the future. 


\section{Notes}

1. With appreciation to Sebastián Mantilla Blanco for influencing the direction this chapter took, and to Paolo Vargiu, Jessica Lawrence, and Jennifer Sellin who commented on earlier versions.

2. Investment law does not have a single or consistent test for corporate nationality. See, Yilmaz Vastardis 2020b.

3. Investment scholars often distinguish between tribunals convened under the International Centre for the Settlement of Investment Disputes ('ICSID'), which has a standing list of arbitrators, and those convened elsewhere, describing only the latter as ad hoc. This glosses over the fact that even within ICSID each panel is convened for the purpose of a single case or set of cases. There are no standing arbitration panels within ICSID.

4. Paolo Vargiu helped me coin this term for the purpose of this Chapter, conveying the inherent (and perhaps intended) chaotic nature of IIL jurisprudence, which sits in opposition to jurisprudence constante.

\section{References}

Arcuri, A. (2020) 'The Great Asymmetry and the Rule of Law in International Investment Arbitration' in Sachs, L., Johnson, L. and Coleman, J. (eds). Yearbook on International Investment Law \& Policy 2018, Oxford University Press.

Balcerzak, F. (2017) Investor-State Arbitration and Human Rights, Brill.

Berge, T. L., and St John, T. (2020) 'Asymmetric diffusion: World Bank's 'Best Practice' and the Spread of Arbitration in National Investment Laws', Review of International Political Economy, DOI: 10.1080/09692290.2020.1719429.

Bonnitcha, J. (2011) 'Outline of a Normative Framework for Evaluating Interpretations of Investment Treaty Protections' in Brown, C. and Miles, K. (eds.). Evolution in Investment Treaty Law and Arbitration, Cambridge University Press.

Botswana and Ghana (2003) Agreement for the Promotion and Protection of Investments, available at https://investmentpolicy.unctad.org/international-investment-agreements/treaties/bilateral-investment-treaties/637/botswana-ghana-bit-2003- [accessed 29 December 2020].

Canada and Burkina Faso (2017) Agreement for the Promotion and Protection of Investments, 2015, available at https://investmentpolicy.unctad.org/international-investment-agreements/treaties/bilateralinvestment-treaties/3557/burkina-faso—canada-bit-2015- [accessed 29 December 2020].

Choudhury, B. (2009) 'Democratic Implications Arising from the Intersection of Investment Arbitration and Human Rights', Alberta Law Review 46.

Coleman, J., Cordes, K.Y. and Johnson, L. (2020) 'Human Rights Law and the Investment Treaty Regime' in Deva, S. and Birchall, D. Research Handbook on Human Rights and Business, Edward Elgar Publishing.

Committee on Economic, Social and Cultural Rights (CESCR) (1966) International Covenant on Economic, Social and Cultural Rights, 993 U.N.T.S. 3.

(1990) GC 2 on International Technical Assistance Measures (Art. 22), U.N. Doc. E/1990/23.

(2000a) GC 14 on the Right to the Highest Attainable Standard of Health (Art. 12), U.N. Doc.

E/C.12/2000/4.

(2000b) Concluding Observations: Italy, U.N. Doc. E/2000/22.

(2001) Concluding Observations: Germany, U.N. Doc. E/C.12/1/Add.68.

(2008) GC 19 on the Right to Social Security (art. 9), U.N. Doc. E/C.12/GC/19.

(2013) Concluding Observations on the Third Periodic report of Japan, U.N. Doc. E/C.12/JPN/

$\mathrm{CO} / 3$.

(2016) GC 23 on the right to just and favourable conditions of work (article 7 of the Interna-

tional Covenant on Economic, Social and Cultural Rights), U.N. Doc. E/C.12/GC/23.

(2017) GC 24 on State Obligations under the International Covenant on Economic, Social, and Cultural Rights in the Context of Business Activities, U.N. Doc. E/C.12/GC24.

(2018) Concluding Observations on the Sixth Periodic Report of Germany, U.N. Doc. E/C.12./

$\mathrm{DEU} / \mathrm{CO} / 6$. 
(2020) GC 25 on Science and Economic, Social and Cultural Rights, U.N. Doc. E/C.12/GC/25.

Dandan, V. (2016) 'Human Rights and International Solidarity: Report to the General Assembly', U.N. Doc. A/71/280.

Davitti, D. (2016) 'Refining the Protect, Respect and Remedy Framework for Business and Human Rights and its Guiding Principles', Human Rights Law Review 16(1).

(2019) Investment and Human Rights in Armed Conflict: Charting an Elusive Intersection, Hart Publishing.

De Schutter, O. (2011) Report of the Special Rapporteur on the Right to Food,U.N.Doc.A/HRC/19/59/ Add.5.

$1(1)$.

(2016) ‘Towards a New Treaty on Business and Human Rights', Business and Human Rights Journal

De Zayas, A. (2015) Report of the Independent Expert on the Promotion of a Democratic and Equitable International Order, U.N. Doc. A/HRC/30/44.

Dommen, C. (2020) 'Human Rights Impact Assessment:Trade Agreements and Indigenous Rights' in Borrows, J. and Schwartz, R. (eds). Indigenous Peoples and International Trade, Cambridge University Press.

Draft Pan-African Investment Code (2016) available at https://au.int/en/documents/20161231/panafrican-investment-code-paic [accessed 4 January 2020].

Eide,A. (1999) The right to adequate food and to be free from hunger. Updated study on the right to food, U.N. Doc. A/CN.4/SUB.2/1999/12.

European Commission (2017) 'Sustainability Impact Assessment (SIA) in support of an Investment Agreement between the European Union and the People's Republic of China: Final Report', available at https://trade.ec.europa.eu/doclib/docs/2018/may/tradoc_156862.pdf [accessed 29 December 2020].

Fahner, J.H., and Happold, M. (2019) 'The Human Rights Defence in International Investment Arbitration: Exploring the Limits of Systemic Integration', International and Comparative Law Quarterly 68(3), 741-759.

Guntrip, E. (2017) 'Urbaser v. Argentina:The Origins of a Host State Human Rights Counterclaim in ICSID Arbitration?', EJIL Talk!, 10 February 2017, https://www.ejiltalk.org/urbaser-v-argentina-the-originsof-a-host-state-human-rights-counterclaim-in-icsid-arbitration/ [accessed 29 December 2020].

Ho, J. (2019) 'The Creation of Elusive Investor Responsibility', AJIL Unbound 113, 10-15.

(2020) 'Hegemony 101 in International Investment Law', AfronomicsLaw 9 September 2020, available at https://www.afronomicslaw.org/2020/09/09/hegemony-101-in-international-investmentlaw/ [accessed 22 September 2020].

Human Rights Committee (2004) GC 31 on the Nature of the Legal Obligations Imposed on States Parties to the Covenant, U.N. Doc. CCPR/C/21/Rev.1/Add.13.

International Centre for Settlement of Investment Disputes (ICSID) (2007a) Enron Corporation and Ponderosa Assets, L.P. v. Argentina, ICSID Case no. ARB/01/3, Award. (2007b) LGEE Energy Corp., LGEE Capital Corp. and LGEE International, Inc. v. Argentina, ICSID Case No.ARB/02/01. (2008a) Biwater Gauff (Tanzania) Ltd.v. Tanzania, ICSID Case No. ARB/05/22, Award. (2008b) Continental Casualty Company v. Argentina, ICSID Case No. ARB/03/9, Award. (2010) Suez, Sociedad General de Aguas de Barcelona SA and Vivendi Universal S.A. v. Argentina, ICSID Case No.ARB/03/19, Decision on Liability ('Suez and Vivendi v. Argentina').

(2012) Occidental Petroleum Corporation and Occidental Exploration and Production Company v. Ecuador, ICSID Case No. ARB/06/11, Award.

(2016) Urbaser S.A. and Consorcio de Aguas Bilbao Bizkaia, Bilbao Biskaia Ur Partzuergo, ICSID Case. No. ARB/07/26, Award.

(2017) Burlington Resource Inc. v. Ecuador, ICSID Case No.ARB/08/5, Decision on Reconsideration and Award.

(2019) ConocoPhillips Petrozuata B.V. et al. v. Venezuela, ICSID Case No. ARB/07/30, Award.

International Convention on the on the Settlement of Investment Disputes between States and Nationals of Foreign States (ICSID Convention) (1966). 
Japan and Colombia (2011) Agreement for the Liberalization, Promotion and Protection of Investment, available at https://investmentpolicy.unctad.org/international-investment-agreements/countries/105/ japan [accessed 29 December 2020].

Karimova, T. (2014) 'The Nature and Meaning of "International Assistance and Cooperation" under the International Covenant on Economic, Social and Cultural Rights' in Riedel, E., Giacca, G. and Golay, C. (eds). Economic, Social and Cultural Rights in International Law, Oxford University Press.

Krajewski, M. (2013) 'Investment Guarantees and International Obligations to Reduce Poverty: a Human Rights Perspective' in Nadakuvukaren Schefer, K. (ed). Poverty and the International Economic Legal System: Duties to the World's Poor, Cambridge University Press.

(2017) 'Ensuring the Primacy of Human Rights in Trade and Investment Policies: Model Clauses for a UN Treaty on Transnational Corporations, Other Business and Human Rights', CIDSE, https:// www.cidse.org/2017/03/03/ensuring-the-primacy-of-human-rights-in-trade-and-investment-policies/ [accessed 18 September 2020].

(2020) 'A Nightmare or a Noble Dream? Establishing Investor Obligations through Treaty-Making and Treaty-Application', Business and Human Rights Journal 5(1), 105-129.

Kube,V. (2019) EU Human Rights, International Investment Law and Participation, Springer.

Lavopa, F. (2015) 'Crisis, Emergency Measures and the Failure of the ISDS System:The Case of Argentina', Investment Policy Brief 2.

Lawrence, J.,Van Ho, T., and Yilmaz Vastardis, A. (2020) 'EU-China Comprehensive Agreement on Investment: A Scoping Study', Heinrich Böll Stiftung, https://www.boell.de/en/2020/12/09/eu-chinacomprehensive-agreement-investment-scoping-study [accessed 22 December 2020].

Lumina, C. (2014) The Negative Impact of the Non-Repatriation of Funds of Illicit Origin on the Enjoyment of Human Rights, U.N. Doc. A/HRC/25/52.

Maastricht Principles on Extraterritorial Obligations of States in the Area of Economic, Social and Cultural Rights (2013) available at https://www.etoconsortium.org/nc/en/main-navigation/library/ maastricht-principles/?tx_drblob_pi1\%5BdownloadUid\%5D=23 [accessed 18 September 2020].

Makoni, M. (2020) 'COVID-19 in Africa: Half a Year Later', The Lancet 20(10), available at https://doi. org/10.1016/S1473-3099(20)30708-8.

McCorquodale, R. and Simons, P. (2007) 'Responsibility Beyond Borders: State Responsibility for Extraterritorial Violations by Corporations of International Human Rights Law', Modern Law Review 70(4), $598-625$.

Mégret, F. (2017) 'Nature of Obligations' in Moeckli, D., Shah, S. and Sivakumaran, S. (eds). International Human Rights Law, 3rd ed., Oxford University Press.

Meshel,T. (2015) 'Human Rights in Investor-State Arbitration: The Human Right to Water and Beyond', Journal of International Dispute Settlement 6(2), 277-307.

Methven O'Brien, C. (2018) 'The Home State Duty to Regulate the Human Rights Impacts of TNCs Abroad: A Rebuttal', Business and Human Rights Journal 3(1), 47-73.

Morocco and Nigeria (2006) Reciprocal Investment Promotion and Protection Agreement, available at https://investmentpolicy.unctad.org/international-investment-agreements/countries/142/morocco [accessed 29 December 2020].

Muchlinski, P. (2016) 'Negotiating New Generation International Investment Agreements' in Hindelang, S., and Krajewski, M. (eds). Shifting Paradigms in International Investment Law: More Balanced, Less Isolated, Increasingly Diversified, Oxford University Press.

New York Convention on the Recognition and Enforcement of Foreign Arbitral Awards (1958).

Nica, A. (2018) 'David Aven v. Costa Rica: An Aftershock of Urbaser v. Argentina?', Kluwer Arbitration Blog, 12 December 2018, http://arbitrationblog.kluwerarbitration.com/2018/12/12/david-aven-vcosta-rica-an-aftershock-of-urbaser-v-argentina/ [accessed 29 December 2020].

Optional Protocol to the International Covenant on Economic, Social, and Cultural Rights (2008) U.N. Doc. A/63/435.

Pelc, K. (2017) 'What Explains the Low Success Rate of Investor-State Disputes', International Organization 71(3), 559-583. 
Perrone, N.M. (2019) 'The “Invisible” Local Communities: Foreign Investor Obligations, Inclusiveness and the International Investment Regime', AJIL Unbound 113, 16-21.

Ruggie, J. (2011) 'UN Guiding Principles on Business and Human Rights, U.N. Doc. A/HRC/17/31.

SADC Model Bilateral Investment Treaty Template (2012) available at https://www.iisd.org/itn/wpcontent/uploads/2012/10/SADC-Model-BIT-Template-Final.pdf [accessed 29 December 2020].

Salomon, M. (2013) 'Deprivation, Causation and the Law of International Cooperation' in Langford, M. et al. (eds). Global Justice, State Duties: The Extraterritorial Scope of Economic, Social and Cultural Rights, Cambridge University Press.

Sattorova, M. (2018) The Impact of Investment Treaty Law on Host States: Enabling Good Governance?, Hart Publishing.

Schneiderman, D. (2010) 'Judicial Politics and International Investment Arbitration: Seeking an Explanation for Conflicting Outcomes', Northwestern Journal of International Law \& Business 30(2), 383-416.

Seck, S. (2011) 'Conceptualizing the Home State Duty to Protect Human Rights', in Buhmann, K., Roseberry, L. and Mette, M. (eds). Corporate Social and Human Rights Responsibilities, Palgrave Macmillan.

Sepúlveda, M. (2006) 'Obligations of "International Assistance and Cooperation" in an Optional Protocol to the International Covenant on Economic, Social and Cultural Rights', 24 Netherlands Quarterly of Human Rights 24(2), 271-303.

Sim, C. (2018) 'Strategies for Addressing Human Rights Violations in Investment Arbitration: Substantive Principles and Procedural Solutions', Human Rights \& International Legal Discourse 12(2), 153-189.

Skogly, S. (2006) Beyond National Borders: States' Human Rights Obligations in International Cooperation, Intersentia.

Sornarajah, M., (2015) Resistance and Change in the International Law on Foreign Investment, Cambridge University Press.

Sri Lanka and China (1986) Reciprocal Promotion and Protection of Investment.

Statute of the International Court of Justice (ICJ Statute) (1946) 1 UNTS 16, Annex.

Svoboda, O. (2020) 'EU Reform Agenda in Defence of the Judicialization of International Economic Law', European Foreign Affairs Review 25(2), 177-196.

Tauli-Corpuz,V. (2016) Report of the Special Rapporteur on the Rights of Indigenous Peoples, U.N. Doc. $\mathrm{A} / \mathrm{HRC} / 33 / 42$.

United States (2012) '2012 US Model Bilateral Investment Treaty', https://ustr.gov/sites/default/files/ BIT\%20text\%20for\%20ACIEP\%20Meeting.pdf [accessed 10 January 2020].

van Genugten, W. (2015), The World Bank Group, the IMF and Human Rights: A Contextualized Way Forward, Intersentia.

Van Ho, T. (2016) 'Is it Already too Late for Colombia's Land Restitution Process?', International Human Rights Law Review 5(1), 60-85.

Vandenhole, W. and Benedek, W. (2012) 'Extraterritorial Human Rights Obligations and the North-South Divide' in Langford, M. et al. (eds). Global Justice, State Duties: the Extraterritorial Scope of Economic, Social and Cultural Rights, Cambridge University Press.

Wandahl Mouyal, M. (2018) International Investment Law and the Right to Regulate: A Human Rights Perspective, Routledge.

Yilmaz Vastardis, A. (2018) 'Justice Bubbles for the Privileged: A Critique of the Investor-State Dispute Settlement Proposals for the EU's Investment Agreements', London Review of International Law 6(2), 279-297.

(2020a) 'Investment Treaty Arbitration as Justice Bubbles' in Schultz,T. and Ortino, F. (eds). Oxford Handbook of International Arbitration, Oxford University Press.

(2020b) The Nationality of Corporate Investors under International Investment Law, Hart Publishing.

Zarra, G. (2018) 'The Issue of Incoherence in Investment Arbitration', Chinese Journal of International Law 17(1), 137-185. 